Journal of Social Sciences 7 (2): 161-167, 2011

ISSN 1549-3652

(C) 2010 Science Publications

\title{
Development of Cultural Management and Inheritance by Community Participation
}

\author{
Pichayapol Nguanthaisong, Souneth Phothisane and Sastra Laoakka \\ The Research Institute of North Eastern Arts and Culture, \\ Mahasarakham University, Maha Sarakham, Thailand
}

\begin{abstract}
Problem statement: Museums were places where all collections, which indicated values of arts and cultural heritages that were useful for learning, were kept. Establishment of museums was successful by having development, systematic management, cultural inheritance, knowledge transferring, participation and support. Approach: This study aimed to study backgrounds of museum development in temples in the area of the lower northeastern, to study current conditions and problems about museum management in temples and cultural management with community participation in the lower northeastern and to study development and management of museum in temples and cultural inheritance by community participation in the lower northeastern. This research was a qualitative research and conducted by literature review and field data collecting with interviewing, observations, focus group discussions and workshops with 170 persons from group of key informants, casual informants and related agencies. Data were analyzed with cultural diffusion theory and presented results in form of descriptive analysis. Results: The study revealed that backgrounds of museum development in temple were initiated by monks, who collected things in old building without systematic exhibition, labeling of donators or source indicating. Most of collections were things in that community such as traditional utensil donated to temple when they were unused and the rest was from other communities. After having many of collections, monks asked community for fund raising to construct museum building in the area of that temple. Moreover, things from discovering of local archeological sites were also kept in museum and there were many visitors. After that an agency of Fine Arts Department came to study and research by using budgets for the second exploring such local archeological sites and then kept in buildings of temple museum. Currently, it was found that; (1) there was a simple management on antiques of 1500-3000 years ago, agricultural equipments aged of 60 yeas up, but they were still lacking of contents to indicate their values and importance and monks played their roles as curators. Collections were temporally kept in some building or under construction for being permanent museum and had not any registration. (2) For cultural inheritance there were activities on annual local traditions of festivals and opened for teachers, students and pupils to study bodies of knowledge in the museum and (3) for participation, temple and community would coordinate teachers to attend meeting on temple activities. Development of museum in temple, it was found that; (1) Body of knowledge management in temple was operated by a working group consisted of curator and museum controller. For museum building, there were exhibitions with good space for allocation and suggestion from experts to register collections. Museum was also provided with car park and toilets both in and outside building. (2) For cultural inheritance, there was indigenous knowledge transfer, local historical investigation, students and teachers came to learn and be trained as guides. (3) In aspect of participation, museum management was in form of collaborated working by meeting, planning, activities providing and decision making. A joint committee was appointed by temple to cooperation among temple, community and schools. Conclusion/Recommendations: Museum development in temple by community participation for supporting body of knowledge in museum and did their duty in maintenance was reducing burdens both of temple and government sector. Museum would be maintained by development of educational benefits for the next generations. Meanwhile, related agencies should support, assist, suggest and frequently survey data of museum in temple. These were for transferring to community with knowledge, development, management and maintenances all collections in museum. Finally, community should provide museum in temple with guide training, security guards and analyzing works step-by-step for further development.
\end{abstract}

Key words: Temple museum, cultural management, cultural inheritance, community participation, cultural diffusion theory, borderless world, Thai society, collecting field data, information technology, community participation

Corresponding Author: Pichayapol Nguanthaisong, The Research Institute of North Eastern Arts and Culture, Mahasarakham University, Maha Sarakham, Thailand 


\section{J. Social Sci., 7 (2): 161-167, 2011}

\section{INTRODUCTION}

Communities in Thai society had their ways of life with happiness for long time than 700 years since Sukhothai Period and this indicated the strength and sustainability of communities. Thai society had firm and big family system that connected with other families as relatives and gathered in form of villages or communities. They assisted, supported, self-reliance and relied each other. In level of family, village and community; Wat or temple was a production and consumption unit like two sides of a coin. Production, transformation, consumption was integrated as a complete and self-balanced holistic from levels of person, family, relative, community, village, cultural society as well as natural resource, environment and technology. In former time, production process of Thai society was self-sufficiency and self-reliance in all levels. They had 4 requisites for sufficient living that were inherited from generation to next generation. This was "Thai lifestyle" based on village, local or Thai indigenous knowledge.

Nowadays, Thai society was rapidly developing and was changed in many aspects as economy, newly industrialized country (Nics), democratic policies and urban society. In aspect of telecommunication Thailand was entered to era of globalization or borderless world. These changes made Thais forgot their roots of Thai civilization. At the same time of globalization, museum management entered to international level. There was more alert in local areas over the country for collecting many things to exhibit in native museums by efforts of private and government sectors, cultural centers, schools, temples, Department of Fine Arts and some private groups. They all had their aims to exhibit development of Thai society; therefore, local museums were established to promote Thai people for good understanding about development in local level (Chonpairot et al., 2009; Sukna et al., 2009).

Establishment of museum in temple and extensive collecting in each temple was caused by the importance of location. Temple was center of community and abbot played his role as the leader and initiated to collect many things; antiques, artifacts, handicrafts, local equipments and rare natural things; for being heritage of the next generation. This made such temple be famous and was announced an affiliation or branch of National Museum (Peter, 1992).

For direction and future trend of museums in Thailand, the government by National Museum had prominent roles on museum affairs to manage, control and support any kind of museum as well as to promote people for their understanding on importance of museum establishment in level of local organization, especially in education and cultural sector
(Mongkhonrat et al., 2008). This enhanced image of museum as a center of learning and cultural identity institute in perspective of Thai society among wind of cultural changes. At present, determination of direction and trend of museums in Thailand was main duty of National Museum to improve, develop and drive all of museum for playing their real roles of museum (Laomi et al., 2009).

Role development of local museums was an important issue that all museums should be aware on benefits of this development that must be inherited to local people, society and the country. People in communities searched for places for keeping their valuable things and the most safety place for all collections for many countries in Asia is "Temple" (Sarakan et al., 2009; Suksri et al., 2010).

Museum was a learning place for people, if it was developed for being a place for long life education it would be a source or factor that supported long life education of people in Thai society and supported Thai society to be a learning society. According to Dictionary Royal Institute defined the meaning of "Museum" as a place who many things were collected and exhibited important things in aspect of culture or science with the aim of educational benefit and entertainment. Normally, museum establishment needed an area or location to collect and exhibit or tell about backgrounds or history for visitors such as national or local museum. Some organization did not have enough area or building, so it could be established in form of a virtual museum by applying with information technology.

Northeastern Part or Isan was interested by private and government sector that caused this part had good potential and readiness for development, especially in future connection with cyberspace. Northeastern Part was a center of various cultures with many of good old arts and cultures, concepts and traditions. These should be handed on the next generation and presented to Thai people and world community. For conditions of museum in temple, there was lacking of personnel to guide for aspect of content, communication and public relation. This research would encourage new methods to be a prototype for presentation patterns of museum in temple for other local development.

This research, therefore, was to study development and management of museum in temple that would be useful for the next generation and museum would be a learning source for local communities that based on continuous learning of indigenous cultural management with community participation.

\section{MATERIALS AND METHODS}

The study was a qualitative research and conducted by collecting in-depth data from documents and related 
researches, collecting field data, content analysis and analyzing data from collecting and records. Research tools were interviewing, observations, focus group discussions and workshops. Research areas were; (1) Thai Farmer Museum, at Wat Pracha Khamaram, Tub Savai Sub-district, Huai Thalaeng District, Nakhon Ratchasima Province, (2) Museum of Pre-historical Antiques at Wat Pa Phra Sabai, Bueng Charoen Subdistrict, Ban Kruat District, Buriram Province, (3) Museum of Antiques at Wat Kok Kruat, Mueang District, Surin Province, (4) Museum of 4 Tribal Thai at Wat Phra That Rueng Rong, Ya Plong Sub-district, Mueang District, Sri Sa Ket Province and (5) Native Museum of Pa Aou Community at Wat Burapha $\mathrm{Pa}$ Aou Nue, Pa Aou Sub-district, Mueang District, Ubon Ratchathani Province. Data form above areas were researched and developed on museum in temple in aspect of management and cultural inheritance, community participation, changing, geographic conditions, community, village and temple environment, tradition, way of life, culture, physical characteristic, economy and social.

Collection of data: The researchers used both of documentary and field study with procedures for meeting aims. Documentary study was conducted by collecting data from related documents, general data and related theories about indigenous knowledge, way of life, patterns of museum in temple and patterns of local community development. Field study was a study in the areas of museum in temple together with communities in lower northeastern part of Thailand included related researches both of domestic and foreign studies and all data, therefore, were analyzed their concepts for being guidelines for this research as:

- Collection of data from related documents and researches on museum in temple, development of cultural management and inheritance by community participation in lower northeastern part of Thailand

- Backgrounds of museum in temple, holistic development of cultural management and inheritance by community participation in lower northeastern part of Thailand; related laws, policies and strategies on museum in temple, development of cultural management and inheritance by community participation in lower northeastern part of Thailand

- Collection of data from related concept, social and cultural theories on museum in temple, development of cultural management and inheritance by community participation in lower northeastern part of Thailand.

- Collection of data from field study

Analyzing and Interpreting of the data: Data were collected, validated and classified by the researchers before analyzing with methodological triangulation. Firstly; data collection, synthesis and analysis was simultaneously conducted over research duration and after finishing of field data collection. All datas; obtained by video recording, tape recording and photographs; was conduct by typology, typological analysis and categorized according to prescribed categories. After that, data was rechecked whether it was completed or not by data triangulation. Data sources were those for cultural inheritance of communities in lower northeastern part of Thailand. Sources that had to examine were; time source for museum in temple establishment; place source for community museum in temple in lower northeastern part of Thailand and person source for people who related to education of museum in temple, museum curators, museum visitors and those who related with local museum in temple.

\section{RESULTS}

Backgrounds of museum development in temples: It was found that all of 5 museums in temple were initiated by monks and constructed museum building in temple's land. Most of collections were things in that community and the rest was from other communities. There were antiques from discovering of local archeological sites that would be lost; this indicated an overview of social development since pre-historic period; then community and monks gathered them all and constructed a building as a museum in temple. Geographical conditions of the lower northeastern was a plateau. Its population had main occupation in agriculture, rice growing and field crops growing, with extra occupations as sericulture, livestock, vegetable growing. For culture and tradition of communities in the lower northeastern part, people in this area normally clung to "Heet Sib Song" (Tradition that is practiced according to ceremony of each month of the year) and "Kong Sib See” (Principle that leaders of the nation had to keep in their minds for the justice in administering the country).

Management and development: (1) Body of knowledge was pre-historical antiques of 1500-3000 years ago, antiques of 700-1000 years, agricultural equipments aged of 60 yeas up, tribal utensils and 


\section{J. Social Sci., 7 (2): 161-167, 2011}

equipments of 4 races; Thai, Khmer, Laotian, Yer and Suay; present agricultural tools. (2) Most of working group and museum curator were monks that lacked body of knowledge in tourist guiding. Museums in temple were operated under temples' environment. Temples and sub-district administrative organization provided money for hiring officers to take care. (3) Budgets for developing were provided by donation from museum visitors and community fundraising to construct permanent building, whereas some temples were under construction their museum in temple. (4) Contents and collections were donated by villagers and most of them were things could be found in their community or discovered from local archeological sites. (5) For exhibition building, some improved old existing building to be museum. Buildings were codesigned by abbots and civil technician with many of designs and structures as; 2-floors reinforced concrete building, 1-floor concrete building, concrete building with wooden floor and tile roof, contemporary Thai building, 6-floor of pagoda style building, 1-floor Thai style building. (6) Composition and working procedures, most of them had a committee to control the construction. Communities had their participation in donation for building construction. Some collections for showing in museum in temple were supports by local organization and an agency of Government University for registration, labeling and classification with starting point of exhibition. For pre-historical antiques that discovered in local area, Depart of Fine Art would directly registered all things, while some museums without registration they had name tag of donator according to number. (7) Museum allocation, there were allocated with parking lots and toilets. Parking lots were wide ground of that temple, while most of toilets were outside of the exhibition building.

Cultural inheritance: (1) Communities promoted and established volunteers, clubs and utensil invention group and community committee for museum management. (2) Community created and coordinated networks in community for its operations with teachers, students, schools and sub-district administrative organization. (3) Public relations were provided with knowledge for people in community via community public address system and community radio to broadcast Dhamma program that connected to museum activities for inviting people to visit and learn body of knowledge in museum. There were various activities as; meeting in temple, in village or in temple at Buddhist Days; villager came to make merit, observe Buddhist precepts, praying poem related to body of knowledge in museum. There were to create cooperative promotion for cultural inheritance. (4) Proving projects for handicraft group promotion to inherit body of knowledge about inventing components in community tradition activities. (5) Cooperation and supporting government sector in many projects as; relationship between community and cultural agency, museum in temple, museum library, sports ground or Dhamma ground in temple for making museums in temple as tourist attraction of community. These activities were in line with policies on development of various state agencies as Sub-district Administrative Organization, Municipality and local Administrative Organization. (6) Establishment of fund or community cultural center with budgets from Provincial Cultural Office. This fund would provide to temples for their body of knowledge management that still had no systematic fund. (7) Protection of local cultural heritage and indigenous knowledge by complying with local traditions. Temple, community, sub-district municipality and sub-district administrative organization studied and organized annual traditions or festivals by arranging local indigenous knowledge inheritance and outdoor exhibition in those festivals. (8) Local knowledge inheritance. Schools created their local curriculum by integrating such curriculum with local history and participated in annual traditional affairs. Moreover, lecturers in provincial universities assigned their students with report works as a fulfillment of their subjects, while teachers brought their pupils to visit museum in temple for learning body of knowledge.

Community participation: (1) Collaborated thinking by; inviting community committee and government agencies to fundraise or provided budget for museum building construction, temple and community monthly meeting, coordinating teachers in schools for their suggestion and participation, while government agencies had their indirect support from outside. (2) Collaborated planning by coordinating with sub-district administrative organization and community committee to plan activities for local traditional inheritance, donating things for exhibition and constructing museum building. (3) Collaborated decision making by Chief Executive of Sub-district Administrative Organization provided temple with personnel included salary for taking care museum in temple and developed as a tourist attraction. (4) Collaborated operating. Temple and community collected things and established a museum in temple, appointed a specific committee to control museum's building construction and then expanded its duty to support community for coordinating with sub-district administrative organization to public relation and with schools to bring 


\section{J. Social Sci., 7 (2): 161-167, 2011}

their pupils to study in museum and participate annual traditions or festivals that organized by temple. (5) Collaborated gaining benefits. Teachers brought their pupils to study in museum and schools created their local curriculum in their education institutes for learning local history. Sub-district administrative organization developed museum in budgeting and supporting with personnel included salary for taking care museum in temple and developed as a tourist attraction. Donation of people in community indicated their ownership of museum in temple while education institutes integrated body of knowledge in museum with their lectures. 6) Collaborated evaluating. Museums in temple was lacking of performance evaluations, reports on development and management to related agencies with museum in form of annual report.

\section{DISCUSSION}

Backgrounds of museum development in temples: Most of them were initiated by monks and constructed a building as a museum in temples. Most of collections were things could be found in their community or discovered from local archeological sites. These indicated an overview of community development since pre-historical period and then community together with monks collected them and established as a museum in temple. Therefore, temples were center of artifacts, former household tools and equipments. Geographic condition of the lower northeastern was a plateau and people had their occupations in agriculture sector as rice and crops grower.

Management and body of knowledge: There was a management committee consisted of community and school. Local scholars and volunteers did their lectures for transferring body of knowledge about museum. Thus museum was a learning place and center of community with many of local knowledge and history. In aspect of working group, there was a monk as a manager and a museum committee consisted of local people who were the real owners of local museum. It would be difficult to establish a museum in temple, if they did not want or interested, therefore, villagers were the most important factor both in term of data and collections' source. Budgets were provided by donation from museum visitors and righteous persons. For community participation; temple committee, subdistrict administrative organization and schools had their participation in management, cultural inheritance and traditional conservation as well as existing indigenous knowledge. Museum in temple was a source of learning and history. In aspect of museum building construction, designs of museum were focused on its utility. Good museum building should meet requirements of utilization and contents of exhibitions. There were many processes of registration, antique analysis, registered number identification, antiques marker, dimensional measurement, photographing, data recording, storing and controlling of these collections moving. These were for protection and safety of invaluable things that could investigate and use as evidences for validation to bring them back. A museum committee was appointed to control, manage, provide with security guards, train students to be little tourist guides. Community donated things for collecting in museum, while temple organized activities in important days to gather villagers for placing importance on museum in temple as community learning source. As above would be made antiques more interesting.

Cultural inheritance was a part to promote community pride by providing museum as community tourist attraction to support their incomes, source of local sports, community market for products exchanging, source of Dhamma practicing and local traditional promotion. Establishment of museum in temple was in form of saving budget by utilizing old building to modify as museum and library for youth to search data via modern information technology. Temple was an educational center for non-formal education system. Community paid their role in protection of invaluable things, coordinating with local administrative organization to allocate some budgets for supporting museum. These would made awareness of such invaluable treasures in the museum. Temple, community and together with related government agencies provided working groups with honorable award or emolument as well as place importance of all related parties. For cultural inheritance, museum in temple should be a source of learning and cultural inheritance with body of knowledge in all exhibitions. Given community with knowledge would foster their consciousness for cherishing their community museum. There was systematic exhibition that presented by monks or schools in the same direction and collections were also under taking care of scientists. Activities were taken place in important festivals to inherit and instill youth's consciousness for placing importance of cultural inheritance by connecting traditions with body of knowledge in museum. Youth would be encouraged to learn about their ancestors' culture that has been practiced from generation to generation.

Community participation: (1) Collaborated thinking by; inviting community committee and government agencies to fundraise or provided budget for museum 


\section{J. Social Sci., 7 (2): 161-167, 2011}

building construction, temple and community monthly meeting, coordinating teachers in schools for their suggestion and participation, while government agencies had their indirect support from outside. (2) Collaborated planning by coordinating with sub-district administrative organization and community committee to plan activities and to discuss with monk in that temple for local traditional inheritance by direct supporting of community. They donated things for exhibition and constructing museum building as well as being responsible persons. Meeting of all parties was for discussing on museum matters and they were consisted of state agencies, teachers, public health officers and community's leader as well. (3) Collaborated decision making by Chief Executive of Sub-district Administrative Organization provided temple with personnel included salary for taking care museum in temple and developed as a tourist attraction. Museum in temple was still lacking of academics who designed, develop the body of knowledge as well as lacking of advisors. (4) Collaborated operating. Temple appointed a museum committee and then expanded its duty to support community for coordinating with subdistrict administrative organization to invite him/her to be a member of committee and with schools to bring their pupils to study in museum and participate with big cleaning in important festival or Buddhist days. Museum in temple was initiated by community for donating antiques and things to establish museum in temple. After that, an abbot together with community appointed a specific committee to control museum's building construction and had a meeting and public relation about networks of art and cultural heritage for acknowledgement of all parties. This meeting was; to focus on project introduction; to explain its principles, objectives, goals and activities; to make initial understanding among officers, local people, temple and community. (5) Collaborated gaining benefits. Teachers brought their pupils to study in museum and schools created their local curriculum in their education institutes for learning local history. Sub-district administrative organization developed museum in budgeting and supporting with personnel as museum officers and developed such museum in temple as a tourist attraction. Donation antiques and things of people in community indicated their ownership of museum in temple while education institutes integrated body of knowledge in museum with their lectures. (6) Collaborated evaluating. Museums in temple was lacking of performance evaluations, reports on development and management to related agencies with museum in form of annual report. Museum management would be succeeded by 2 groups of people as; (1) Group of government officer, they should have knowledge and understanding of actual meaning of "Participation." They were available to promote and enhance participation among local people and other sectors in any related matters with conservation and development of art and cultural heritage that existed in all local areas of Thailand. These were not any idea of authoritarianism, that supposed to be only the owner of these art and cultural heritage, caused by having authority to control, maintain, restore and conserve national art and cultural heritage instead of Thai people and (2) Group of local people in community. From fundamental of culture in Thai society in any region, there was strength of respect on elder people. Leaders of community were either in formal leadership or informal leadership. When they had knowledge, understanding and awareness on values of art and cultural heritage, it would be easier to promote community participation, whereas that community must have distinct cultural heritage and people in community was ready to follow their leader for participating with all activities taken place by museum in temple.

\section{CONCLUSION}

The purpose of this study was to study backgrounds of museum development in temples in the area of the lower northeastern, to study current conditions and problems about museum management in temples and cultural management with community participation in the lower northeastern and to study development and management of museum in temples and cultural inheritance by community participation in the lower northeastern. The results revealed that backgrounds of museum development in temple were initiated by monks, who collected things in old building without systematic exhibition, labeling of donators or source indicating. Most of collections were things in that community such as traditional utensil donated to temple when they were unused and the rest was from other communities. For current conditions, it was found that; there was a simple management on antiques of 1500-3000 years ago, agricultural equipments aged of 60 yeas up, but they were still lacking of contents to indicate their values and importance and monks played their roles as curators. For cultural inheritance there were activities on annual local traditions of festivals and opened for teachers, students and pupils to study bodies of knowledge in the museum. For participation, temple and community would coordinate teachers to attend meeting on temple activities. Development of museum in temple, knowledge management in temple was operated by a working group consisted of curator, 
museum controller and Sub-district Administrative Organization that supported museum with personnel and budget. For cultural inheritance, there was indigenous knowledge transfer, local historical investigation, students and teachers came to learn and be trained as guides. In aspect of participation, museum management was in form of collaborated working by meeting, planning, activities providing and decision making. A joint committee was appointed by temple to cooperation among temple, community and schools. In conclusion, museum development in temple by community participation for supporting body of knowledge in museum and did their duty in maintenance was reducing burdens both of temple and government sector. Museum would be maintained by development of educational benefits for the next generations. Meanwhile, related agencies should support, assist, suggest and frequently survey data of museum in temple. These were for transferring to community with knowledge, development, management and maintenances all collections in museum. Finally, community should provide museum in temple with guide training, security guards and analyzing works step-by-step for further development.

\section{REFERENCES}

Chonpairot, M., S. Phothisane and P. Sudhisansophon, 2009. Guideline for conservation, revitalization and development of identity and customer of kula ethnic group of the Northeast Thailand. Soc. Sci., 4: 167-173.
Laomi, B., S. Chantachon and N. Wongphongkham, 2009. A model of pulpit conservation and revitalization using community participation of phu-thai people in Northeast Thailand. J. Soc. Sci., 5: 374-376.

Mongkhonrat, P., S. Chantachon and S. Postisarn, 2008. The status and roles of public benefit organizations in social and cultural changes for Thailand. Soc. Sci., $\quad 3$ : 256-260. 10.3923/sscience.2008.256.260

Peter, C.B., 1992. Collections storage I: Storage of ecclesiastical textiles in Lyon, museum management and curatorship. 11: 212-213. DOI: 10.1016/0964-7775(92)90031-Y

Sarakan, P., S. Phothisane and T. Pantachai, 2009. Cultural combination of basic beliefs of buddhism, brahman and spirit worship towards the stability of the Isan community. Eur. J. Soc. Sci., 10: 462-467.

Sukna, S., S. Laoakka and T. Krairach, 2009. The development of natural pigments in esaan folk wisdom for usage of painting. J. Soc. Sci., 5: 471-473.

Suksri, A., S. Phothisane, S. Laoakka, N. Thongwol and B. Saenyabud, 2010. The buddha images and conservation and adherence to cultural values in Northeast. J. Soc. Sci., 6: 320-323. 